\title{
Kaynamamalarda serbest vaskülarize fibula grefti ile rekonstrüksiyon
}

\author{
Reconstruction of non-unions with free vascularized fibular graft
}

\author{
A. Mehmet Demirtaş, Cihan Kırçıl
}

Memorial Hastanesi, Ankara

\begin{abstract}
Kırıkların cerrahi tespitindeki güncel teknolojik gelişmelere rağmen, kaynamama halen bilinmeyenleri olan klinik bir sorundur. Azalmış çevresel vaskülaritenin oynadığı rol göz önüne alındığında, mikrocerrahi yöntemlerin kullanıldığı vaskülarize kemik greftleriyle yapılan rekonstrüksiyonlardaki anlamlı derecede yüksek başarı oranı, bu yöntemin kaynamamalardaki standart cerrahi yöntemler arasında anılmasını sağlamaktadır. Özellikle serbest vaskülarize fibula grefti, morfolojik özellikleri itibariyle, gerek alt gerekse üst ekstremite uzun kemiklerindeki psödoartrozun tedavisinde, tüm vaskülarize kemik greftleri içerisinde altın standart konumundadır. Mikrocerrahi tecrübe gerektirmesi, nispeten uzun cerrahi süresi ve buna bağlı komplikasyonlar, donör saha sorunları ve benzeri olumsuz faktörlere rağmen, periosteal ve endosteal kan akımının korunduğu bir serbest greftle yapılan rekonstrüksiyon neticesinde tatminkar kaynama sonuçlarının elde edilmesi, deneyimli ve donanımlı bir ekiple ve isabetli bir ameliyat öncesi planlamayla uzak ihtimal olmaktan çıkar.
\end{abstract}

Anahtar sözcükler: serbest vaskülarize fibula grefti; kaynamama; kırık; mikrocerrahi
Non-union still is a clinical problem with unknowns although current technological advancements of surgical fixation techniques for fractures. When considered the role of poor local vascularity, significant success rate of reconstructions with free vascularized bone grafts which is performed via microsurgical techniques enables this method to be mentioned among standard surgical methods for the treatment of non-unions. Especially free vascularized fibular graft is gold standard option among other vascularized free bone grafts regarding its morphological features to treat pseudo-arthrosis of long bones in both lower and upper extremities. Although unfavorable factors such as requiring high degree of microsurgery experience, relatively longer surgery period and associated complications, donor site problems, the use of free vascularized fibular graft which protects endosteal and periosteal blood stream gives satisfactory union rates, also thanks to experienced and equipped surgical team, and well-directed preoperative planning.

Key words: free vascularized fibular graft; non-union; fracture; microsurgery

\section{KAYNAMAMA VE GECIKMIŞ KAYNAMADA VASKÜLARITENIN ROLÜ}

Kaynamama ve gecikmiş kaynamada görülen, kırık iyileşmesindeki reperatif fazdan remodeling fazına geçişteki fibroblastik kallusun ossifikasyonundaki defekte neden olarak sekonder kırık iyileşmesini engelleyen ekstensil travma, kemik kaybı, stabil olmayan tespite bağlı prematür kırık mobilizasyonu, enfeksiyon, geniş osteonekroz, ileri yaş gibi nedenlerin arasında sayılabilecek belki de en önemli faktör, azalmış çevresel vaskülaritedir. Bilindiği gibi, kırık iyileşme sürecinin, kırı̆̆ın 6-9. ayı itibariyle tamamiyle durmuş olması kaynamama olarak değerlendirilmektedir. Klinik olarak kırık bölgesinde hareket ve ağrı mevcudiyeti ve radyolojik olarak kırık hattında birleşmenin bulunmadığı atrofik veya hipertrofik kallus formasyonun eşlik edebildiği bu tabloda, kırık bölgesi kanlanmasının yetersizliğinin ana etmenler arasında olduğu bilinmektedir. Özellikle atrofik kaynamama olguları, bozulmuş bölgesel kanlanma ile ilintilidir. Ekstensil travma, çok parçalı kırıklar, yaralanmanın kendisine veya dışarıdan uygulanan kapalı manipülasyonlara bağlı nütrient arter hasarı, geniş kemik defektleri, aşırı periosteal sıyrılma ve yetersiz stabilizasyon gibi faktörler de sürece katkıda bulunur. ${ }^{[1]}$ Bir hayvan modeli çalışmasında, kırığın 1. haftasında, kırık sahasındaki kan damarı miktarının immünolokalizasyon ile, atrofik non-union grubunda normal gruba

- Illetişim adresi: Prof. Dr. A. Mehmet Demirtaş, Memorial Ankara Hastanesi, Balgat Mah., Mevlana Blv. 1422. Sok. No: 4, 06520 Çankaya, Ankara Tel: 0312 - 2536666 e-posta: demirmeh@yahoo.com

- Geliș tarihi: 1 Kasım $2017 \quad$ Kabul tarihi: 1 Kasım 2017 
nazaran belirgin olarak daha az olduğu tespit edilmiş olup, kırı̆ıı 8 . haftası itibariyle iki grupta aynı seviyelere ulaştığı gözlenmiş. ${ }^{[2]}$ Buradan hareketle kaynamama olgularında azalmış vaskülaritenin erken dönemde arttırılması kaynamama durumuna karşı koruma sağlayabileceği çıkarımında bulunulmuş. Ayrıca, açık kırık ve degloving tarzı yüksek enerjili yaralanmalarda ve diyafizyel kırıklarda söz konusu olan mutlak veya rölativ hipovaskülarite zemininde kaynamama daha sık görülmektedir. Bu minvalde, bu kaynamama ve gecikmiş kaynama olgularının tedavisinde bölgesel kanlanmayı daha etkili bir şekilde yeniden temin etmek suretiyle uygulanan vaskülarize kemik greftleriyle rekonstrüksiyon işlemleri, mikroanastomoz tekniklerinin gelişmesiyle standart tedavi protokolleri arasında yerini almış bulunmaktadır. Travmatik kaynamama olgularının yanında tümör rezeksiyonları, osteomiyelit, konjenital psödoartroz ve radyasyon nekrozu gibi durumlarda da serbest vaskülarize kemik grefti ile rekonstrüksiyon tedavisi tercih edilmektedir.

\section{VASKÜLARIZE KEMIK GREFTI ILE REKONSTRÜKSIYON}

Günümüzde yaygın olarak uygulanan mikrocerrahi yöntemle vaskülarize kemik flebi transferinin geçmişine gidilecek olursa, 70'li yıllarda Ostrup ve ark. ile Doi ve ark.'nın çalışmalarında, köpekler üzerinde mikrovasküler teknikle kaburga greftleri mandibulaya transfer edilmiş ve sonuçlarının başarılı olduğu bildirilmiştir. Bu çalışmalarda, damarlı kemik greftlerinin medüller ve periostal dolaşımlarının korunması sonucu canlı kaldığı ve creeping substitution'a maruz kalmadan iyileşmenin sağlandığı gösterilmiştir. ${ }^{[3,4]} 1975$ yılında ise, ilk kez bir klinik olguda, serbest vaskülarize fibula grefti (SVFG) geleneksel kemik greftleme yöntemlerinin başarısız olduğu geniş bir tibia defekti olgusunun rekonstrüksiyonunda Taylor ve ark. tarafından kullanılmıştır. Daha sonra çeşitli çalışmalarda, bu yöntemin travma sonrası uzun kemik defektleri, tümör eksizyonu, ve radyasyon sonrası oluşan defektler, doğumsal tibia psödoartrozu, üst ekstremitenin konjenital ve kazanılmış kemik defektleri gibi durumlarda uygulanabilirliği gösterilmiştir. ${ }^{[5-8]}$

Tarihsel süreçte, vaskülarize kemik greftlerinin kaynamama ve benzeri komplike olgularda geleneksel greftleme yöntemlerinin yerine tercih edilmeye başlanmasındaki ana faktör, patolojik bölgedeki çevresel vaskülaritenin yetersizliği olmuştur. Vaskülarize kemik greftlerinde dahili kan akımının devam etmesiyle, kemik kaynamasına ve greft hipertrofisine olanak sağlanmış olur. ${ }^{[9]}$ Bu durum aynı zamanda, grefti enfeksiyona daha dirençli kılar, daha hızlı iyileşme ve hipertrofi nedeniyle mekanik yüklenmeler daha iyi tolere edilebilir ve bu şekilde greft rezorpsiyonu ve stres kırı̆gı insidansı azalır. ${ }^{[10]}$ Peat ve ark., yaptıkları çalışmalarında, vaskülarize kemik greftinin, gecikmiş konvansiyonel kemik grefti ve erken dönemde gerçekleştirilen konvansiyonel kemik greftine göre çok daha başarılı sonuçlar verdiğini bildirmişlerdir. ${ }^{[11]}$

Vaskülarize kemik greftlerinin konvansiyonel yöntemler üzerindeki diğer bir avantajı, transferden sonra hipertrofiye uğramasıdır. Hipertrofi oranı, birinci yılda $\% 43$, ikinci yılda $\% 80$ olarak bildirilmiştir. ${ }^{[12,13]}$ Hipertrofinin tam mekanizması bilinmemekle beraber, mekanik yüklenmenin bunda etkili olduğu, bu yüzden alt ekstremiteye transfer edilen greftlerde hipertrofinin daha fazla olduğu rapor edilmiştir. ${ }^{[13-15]}$

Damarlı kemik grefti olarak, fibula, iliak kanat ve bu ikisinin uygun olmadığı durumlarda kaburgalar kullanılabilmektedir. ${ }^{[16]}$ Fibula morfolojisi, yeterli uzunlukta olması, biyomekanik özellikleri ve vasküler pedikülünün yapısı itibariyle, uzun kemiklerdeki kaynamama olgularının rekonstrüksiyonunda diğer serbest kemik fleplerine nazaran ilk tercih haline gelmektedir. ${ }^{[15,17]}$ Özellikle $10 \mathrm{~cm}$ 'den büyük kemik defektleri için seçilebilecek en optimal yöntem SVFG transferi olmalıdır. ${ }^{[18]}$

Ciddi arterioskleroz gibi ek vasküler komorbidite durumlarında, önceki travmaya bağlı bacakta tek damar varlığında, sigara tiryakiliği durumunda, göğüs travması ve her iki fibulanın kırık olduğu iki taraflı bacak travmasında, damarlı kemik grefti transferi yerine distraksiyon osteogenezi gibi diğer yöntemleri seçmek daha doğru olabilir. ${ }^{[15]}$

Son dönemlerde mikrocerrahi tekniklerdeki ilerlemeler ile, SVFG gibi vaskülarize kemik greftlerinin büyük iskelet defektlerinde daha yaygın kullanılabilmesinin önünün açılmasıyla[19], travmatik defektif psödoartroz olgularının rekonstrüksiyonunda özellikle serbest vaskülarize fibula grefti standart seçenekler arasında yerini almıştır. ${ }^{[20]}$ SVFG, yeterli bir vasküler pedikülle, $25 \mathrm{~cm}$ uzunluğunda yüksek dansiteli kortikal kemik sağlamasından dolayı bu gibi kemik defektlerinde ilk tercihlerdendir. ${ }^{[21,22]}$ Verici alandaki sınırlı morbidite de bu grefti cazip kılan faktörlerden olup ${ }^{[16]}$ bu nedenlerle SVFG uzun kemik defektlerinde kullanılabilecek en optimal greft olarak düşünülür. ${ }^{[23]} \mathrm{Bu}$ tekniğin en kullanışlı olduğu bölgenin ise femur orta şaft bölgesi olduğu bildirilmiştir. [24]

Taylor ve ark.'na göre, SVFG greftinin avantaj ve dezavantajları aşağıdaki şekilde sıralanır. ${ }^{[25]}$

Avantajlar:

1. Tek basamaklı bir işlemdir.

2. Greft, alıcı kemiğin içine anostomoz sırasında stabiliteyi arttırmak için proksimalden ve distalden sabitlenebilir. 


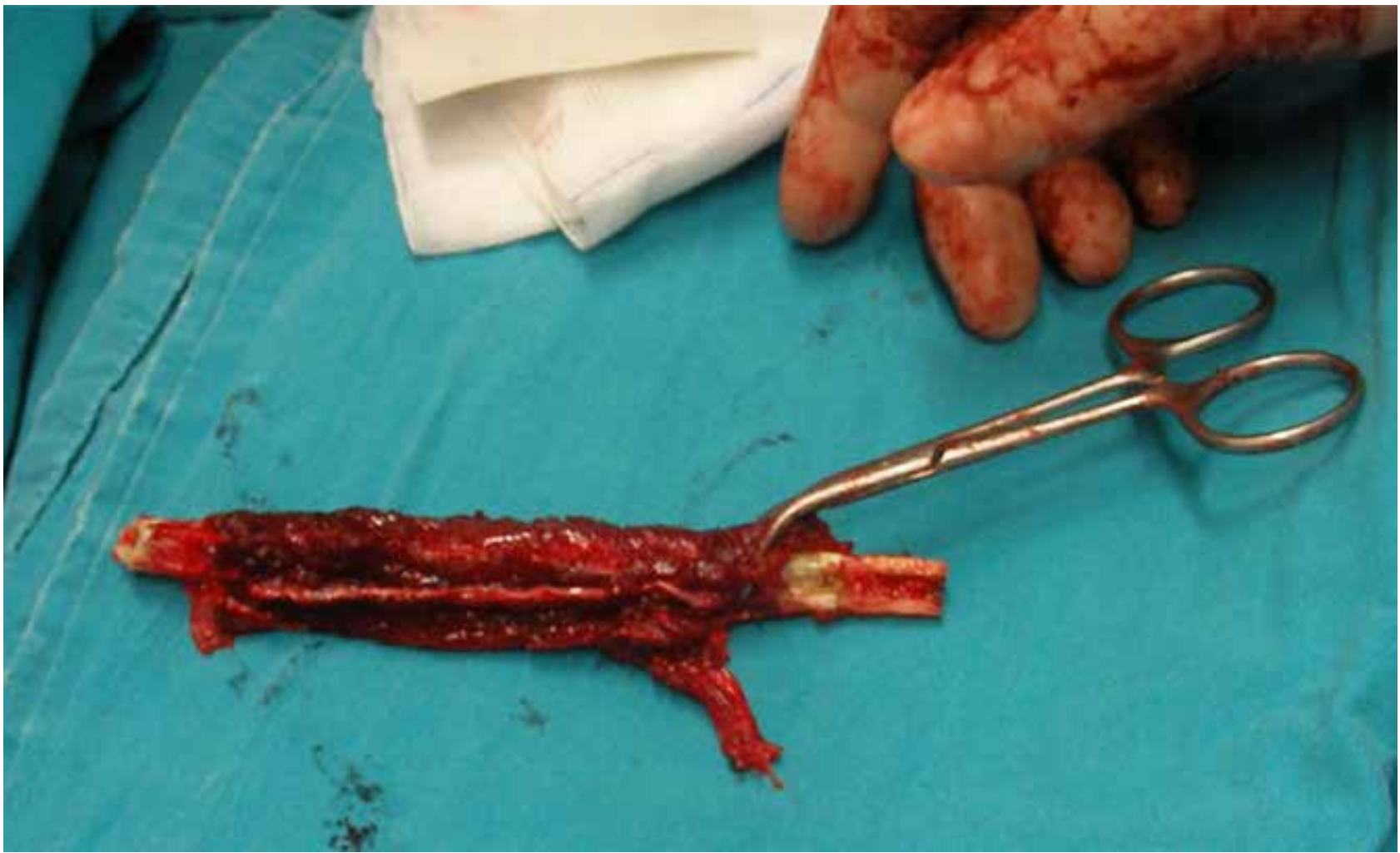

Şekil 1. Serbest vaskülarize fibula grefti pedikülü ile birlikte görülmekte.

3. Tübüler kemik kısmi (onlay) kortikal kemikten daha sağlamdır.

4. Hem endosteal hem de periosteal dolaşımlı iyi kanlanan canlı bir kemik transfer edilir.

5. Eğer anastomozlar başarısız olursa, nakledilmiş olan fibula, geleneksel non-vaskülarize kortikal kemik grefti olarak işlev görebilir.

Dezavantajlar:

1. Prosedür elektif olarak yapılmalıdır.

2. Ameliyat süresi daha uzundur. Bu nedenle, ek morbiditeleri daha fazla olan ileri yaşlı hastalarda tercih daha kısıtlı olabilmektedir.

3. Anastomozun açıklığının cerrahi sonrası değerlendirilmesi çok zordur.

4. Diz ve ayak bileğinde problemlere sebep olabilecek donör saha morbiditesi olabilir.

5. Alıcı ve verici ekstremitede bir ana damar feda edilmektedir.

\section{CERRAHI TEKNIK}

Kaynamama bölgesindeki kemik (ve varsa yumuşak doku) defektinin büyüklügüne göre fibula (ve cilt adasının) büyüklügü saptanmalıdır. Alıcı sahada yeterli debridman yapılarak hazır hale getirilir. Vasküler yapıların uygunluğu ile ilgili şüpheli bir durum söz konusuysa anjiyografi ya da Doppler ultrasonografi ile vasküler yapılar görüntülenmelidir. Bundan sonra, alıcı sahada fibulanın tespiti ve damar anastomozları için insizyonların planlaması yapılmalıdır. Tespit ve anastomozun her ikisi tek insizyondan yapılabileceği gibi, ayrı ayrı insizyonlarla da yapılabilir.

Vaskülarize serbest fibula greftinin alınacağı ekstremiteye turnike uygulanır. Fibula ile birlikte cilt flebi de alınacaksa, ne kadar büyüklükte olacağı ameliyattan önce belirlenmelidir. Bu flep, peroneal arterden beslenen perforan bir fleptir. Septokutanöz, septomusküler ve muskülokutanöz perforan dallarca beslenir. ${ }^{[26]}$ SVFG'nin pedikülünün yaklaşık uzunluğu, peroneal arter ve eşlik eden venleriyle birlikte, ortalama $6-8 \mathrm{~cm}$ uzunluğundadır (Şekil 1). Peroneal arterin bifurkasyonu yaklaşık olarak fibula başının $7 \mathrm{~cm}$ distalindedir. Fibulanın nütrisyonel arteri büyük çoğunlukla orta $1 / 3$ 'te olmakla birlikte (\%77), \%19 oranında üst $1 / 3$ 'te ve $\% 4$ oranında alt $1 / 3$ 'te yer alır. ${ }^{[27]}$

Cilt flebiyle birlikte alınacaksa, bu flep septumda izole edilir. Cilt flebi alınmayacaksa, lineer insizyonla 
direkt fibula üzerinden girilir. Fibula üzerindeki fasya açılarak kompartmanlar ve peroneal kaslar görülür. Bu sırada superfisiyel peroneal sinirle karşılaşılabileceği unutulmamalı ve korunmalıdır. Peroneal kaslar belirlendikten sonra bu kasların posteriorunda kasları soleustan ayıran fibroadipöz doku görülür. Bu gevşek fibroadipöz septum, üzerindeki cildi de besleyen perforan vasküler yapıları içermektedir. Soleus proksimale doğru fibuladan ayrılır ve proksimalde derinde venler görülür. Peroneal kaslar daha sonra distalde periost korunacak şekilde ayrılır ve bu sırada peroneal sinire dikkat edilmelidir. Böylece, anterior kompartmandaki peroneal kaslar, ekstansör hallusis longus, ekstansör dijitorum izole edilerek interosseöz membrandan kaldırılır. Bu sırada fibula üzerinde, arzu edilen büyüklüğe göre osteotomi yerleri belirlenmelidir. Fleksör hallusisin disseke edilmesiyle peroneal damarlar ortaya çıkar. Fleksör hallusis mobilize edilerek distal osteotomi yapılır. Osteotominin distalinden peroneal damarlar bağlanır. Daha sonra fibula hafif mobilize edilerek peroneal damarların fibulaya giriş noktası görülür ve peroneal damarlar tibialis posteriora kadar izlenir. Daha sonra proksimal osteotomi yapilır. Sadece flep pedikülü ile tibialis posterior damarına bağlı hale gelir. Turnike açılarak flebin kanlanması kontrol edilir.

Damarlı fibula greftinin disseksiyonu yapılırken başka bir ekip tarafından alıcı alan hazırlığı yapılmalıdır. Kemik uçları tespite uygun hale getirilmelidir. Damar anastomozları için alıcı tarafta uygun arter ve venler hazırlanmalıdır. Fibulanın konturları düzeltilerek humerus, femur ve tibiada fibulanın uçları kemiğin içine sokularak her iki uçta vida, köprüleyen plak ya da eksternal fiksatörle tespit edilebilir. Önkolda ise fibula ile önkol kemiklerinin çapları benzer olduğu için uç uca tespit yapılabilir. Alıcı ve donör saha dren konularak kapatilır.

\section{ALT EKSTREMITEDEKI UYGULAMALAR VE SONUÇLARI}

Alt ekstremite uzun kemiklerinin yüksek enerjili yaralanmaları ile oldukça sık karşılaşılmaktadır. Defektif ve özellikle enfekte kaynamamaların tedavisinde önceleri erken ampütasyon yapılırken, günümüzde ekstremite koruyucu girişimler daha ön plana çıkmıştır.

Geleneksel greftleme yöntemleri, greftlerin yavaş ve tam yetersiz neovaskülarizasyonundan dolayı geniş defektlerin tedavisinde yetersiz kalmaktadır. ${ }^{[28]}$ Damarlı kemik fleplerinde intrensek kan akımı korunduğu için büyük boylarda flepler kemik ve çevre yumuşak dokuların canlılığı korunarak transfer edilebilmekte ve büyük defektler bu şekilde rekonstrükte edilebilmektedir. Özellikle SVFG 6 cm'den büyük defektlerin tedavisinde, diğer vaskülarize fleplere olan avantajlarından dolayı, alt ekstremite uzun kemiklerinin defektif kaynamamalarının tedavisinde, fiksatör yardımlı segment kaydırma yöntemine alternatif olarak kullanılır. ${ }^{[29]}$ Bunun yanında, böyle bir prosedürün uygulanmasının kendine özgü dezavantajları da vardır. Cerrahi ekibin mikrocerrahi konusunda oldukça deneyimli olması gerekmektedir. Bu nedenle, SVFG ile ilgili yeterli tecrübesi bulunmayan cerrahlar, tibia ve femurdaki büyük defektler için eksternal fiksatör yardımlı segment kaydırma prosedürlerini tercih etmektedir. Yokoyama ve ark., yapmış oldukları çalışmada, fiksatör yardımlı segment kaydırma yöntemiyle SVFG yöntemini karşılaştırmışlar ve sonuç olarak hasta grupların fonksiyonel sonuçlar ve kaynama oranları bakımından anlamlı fark olmadığını belirtmişlerdir. ${ }^{[30]}$

Tibia rekonstrüksiyonlarında SVFG, silindirik şekli, mekanik dayanıklılığı, pedikülünün belirgin olması ve hipertrofi potansiyeli nedeniyle en uygun tedavi yöntemlerinden biridir. Femurun ve tibia kesit alanının fibulanınkinden oldukça büyük olmasından dolayı, transfer edilen fleplerde stres kırıkları oluşması ihtimali oldukça yüksektir. Bu şekilde oluşabilecek kesit alanı farkını minimalize etmek için pedikülü korumak suretiyle flebi ikiye katlamak, iki adet SVFG kullanmak, SVFG ile birlikte allogreft kullanmak gibi alternatif yöntemler tercih edilebilir. ${ }^{[31,32]}$

Serbest vaskülarize fibula greftlerinin alt ekstremitedeki rekonstrüksiyonlarda, konvansiyonel kullanımından başka, farklı tekniklerle de uygulanabildiği görülmektedir.

\section{Vaskülarize Proksimal Fibula Grefti}

Bu greft tekniği, kemik büyümesinin devam ettiği çocukluk çă̆ı osteoartiküler defektlerinde endike olabilmektedir. ${ }^{[3]}$ Remodeling potansiyelinden dolayı proksimal humerus, distal radius ve proksimal femur defektlerinde başarılı sonuçlar bildirilmiştir. ${ }^{[34-36]}$ Distal tibia mediyal yüzdeki defektler de vaskülarize proksimal fibula greftiyle başarılı bir şekilde rekonstrükte edilebilir. ${ }^{[37]}$

\section{Onlay Greftleme}

Kısmi kortikal defektlerin tedavisi için SVFG, uzun aksı yönünde boydan boya osteotomize edilerek bir tarafında kortikal, diğer tarafta spongiyöz kısım olan flep olarak kullanılabilir. ${ }^{[38]}$

\section{Çift Namlu Tekniği}

Periosteal kan akımı korunarak ve mevcut SVFG ikiye katlanarak, kesit yüzey alanı arttırılabilir. Jupiter ve ark., bu teknikte flebin orta noktasına yakın bir 
yerden sağlam periosteal menteşe kalacak şekilde osteotomize edilmesini önerirken, başka yazarlar eşit olmayan iki parçaya bölünmesini ve uzun olan kısmın kanal içine gömülmesini önermektedirler. ${ }^{[39,40]}$ Sıklıkla $13 \mathrm{~cm}$ 'den kısa proksimal tibia veya femur defektleri için kullanılır. ${ }^{[41]}$ Bu bölgelerin daha büyük defektlerinin tedavisi için, her iki fibulanın kullanılması gerekmektedir. ${ }^{[42]}$

\section{Hibrid Greftleme}

Hibrid greftlemede, SVFG ile birlikte masif allogreft kullanımı da söz konudur. Capanna ve ark., alt ekstremitenin geniş defektlerinin tedavisinde hibrid greftlemeyi bildirmişlerdir. ${ }^{[32]}$ SVFG allogreftin medullasında açılan kanala yerleştirilir ve flebin pedikülü allogreftten açılan kortikal pencereden çıkarılarak anastomoz yapılır. ${ }^{[43]}$ Hibrid greftleme femur ve tibiada geniş rezeksiyon yapılan, beklenen yaşam süresi uzun olan, özellikle aktif genç hastalarda tercih edilebilmektedir. ${ }^{[44]}$ Bu teknik için tek relatif kontrendikasyon, daha önceden bulunan derin enfeksiyondur. ${ }^{[45]}$

\section{Kompozit Doku Transferi}

Peroneal arter pedikülünden beslenen cilt komponenti bulunan SVFG, yumuşak doku kayıplarının da eşlik ettiği yaralanmalarda iyi bir tedavi alternatifidir. Cilt flebi eliptik şekilde ve uzunluğu en fazla $20 \mathrm{~cm}$, genişliği de $10 \mathrm{~cm}$ kadar olmalıdır. Kompozit dokudaki cilt kısmı yumuşak doku örtünmesini sağlarken, aynı zamanda SVFG'nin kanlanmasının durumuyla ilgili bilgi de sağlar. Kas dokusu transferi gerektiren durumlarda hallusis longus kas flebi de içeren SVFG alınabilir. ${ }^{[31]}$

Sebebi ne olursa olsun, geniş kemik defektli kaynamama olguları ortopedistler için tedavisi güç durumlardır. Defektin $6 \mathrm{~cm}$ 'den büyük olduğu ve fiksatör üzerinden segment transferinin gerçekleştirilemediği durumlarda, SVFG güvenilir bir tedavi alternatifidir. Proksimal tibia veya femurdaki geniş defektler, SVFG ikiye katlanarak veya masif allogreftlerle birlikte kullanılarak başarılı bir şekilde tedavi edilebilir. SVFG cilt ve yumuşak doku defektlerinin eşlik ettiği yaralanmalarda cilt, faysa, kas içeren kompozit doku şeklinde alınmış flepler kemik ve yumuşak doku defektlerinin tek flep ile kapatılmasına olanak sağlar.

\section{ÜST EKSTREMITEDEKI UYGULAMALAR VE SONUÇLARI}

Ilizarov yöntemiyle distraksiyon osteogenezisi kullanılarak kemik transferi, alt ekstremitedeki kemik kayıplarının onarımında geniş yer bulmaktadır. Üst ekstremitede ise, bazı konjenital deformiteler ve spesifik kemik kayıpları dışında, uygulama sınırlıdır. ${ }^{[46,47]}$ Ortalama $4 \mathrm{~cm}$ uzama için dört ay fiksatör kullanılması gerekmektedir ve uzatma sonrası rotasyonel problemlere yol açabilmektedir. ${ }^{[48]}$

Kemik defekti $6 \mathrm{~cm}$ 'den fazla olduğunda, damarlı fibula nakli altın standart yöntemdir. ${ }^{[48-50]}$ Defekti çevreleyen yumuşak doku vaskülarizasyonu zayıf olduğunda veya skar dokusunun var olduğu gibi yumuşak doku örtüsünün yetersiz olduğu durumlarda, damarlı fibula nakli daha önemli hale gelmektedir.

Humerus rekonstrüksiyonunda stabil internal tespit önemlidir. Genellikle, uzun kompresyon plaklarının kullanımı yeterlidir (Şekil 2). Humerusta defektin diyafizin ortasında olduğu durumlarda, her iki ucun intramedüller impaksiyonuyla beraber transkortikal vidalanması ya da Steinman kullanılarak tespiti de yardımcı olabilir. Humerusun proksimalindeki defektlerde ise, humerus başı ile fibula arasında intramedüller tespit ya da rekonstrüksiyon plağı kullanılarak, daha kompleks bir tespit yöntemi kullanılmalıdır. Humerusta lateral insizyonla humerusun ortaya konulması ve kemiğin tespiti sağlanırken, mediyal insizyonla da anastomoz yapılacak damarlar ortaya konulur. Bu yaklaşımla, brakiyal artere uç yan anastomoz yapılırken, brakiyal, sefalik ve bazilik venlere uç uca anastomoz yapılabilir. Mediyal insizyon kullanılarak damarsal yapılara ulaşılırken, aynı zamanda retrograd olarak fibula tespit edilebilir. Kemik kaynamasının ilk belirtileri görülür görülmez harekete başlanabilir. Greft, alt ekstremitedeki gibi yük taşımayacağından, greftin hipertrofisi beklenmez.

Penetran travma, enfekte kaynamama ya da tümör rezeksiyonu sonrası radius ve ulnada geniş defektler oluşabilmektedir. Fibula, kesit ve şekil olarak önkol kemiklerinin diyafizer kısımlarına benzemektedir. Bu benzerlik nedeniyle, kemik tespiti de uç uca kompresyon plakları kullanılarak yapılabilmektedir. Genellikle proksimal ve distalde altı korteks tespit yeterli olabilmektedir. Internal tespit yapıldığında, ek olarak ameliyat sonrası kol askısı ile desteklemek gerekmektedir. Metafizer impaksiyon yapılabildiğinde, transkortikal vida tespiti de yapılabilir. Ulnar ya da radyal damarlar uç uca ya da uç yan olarak anastomoz için yeterli çapa sahiptir. Damarlı fibula greftleri radius distal uç tümörlerinde, el bileği artrodezi ile birlikte ya da olmadan kullanılabilmektedir.

\section{KOMPLIKASYONLAR}

Anastomoz hattında tromboz, kaynamama, stres kırıkları, enfeksiyon ve duyusal anormallikler, motor güç kaybı, ayak bileği ağrısı gibi donör saha morbiditeleri en sık görülen komplikasyonlardır. 


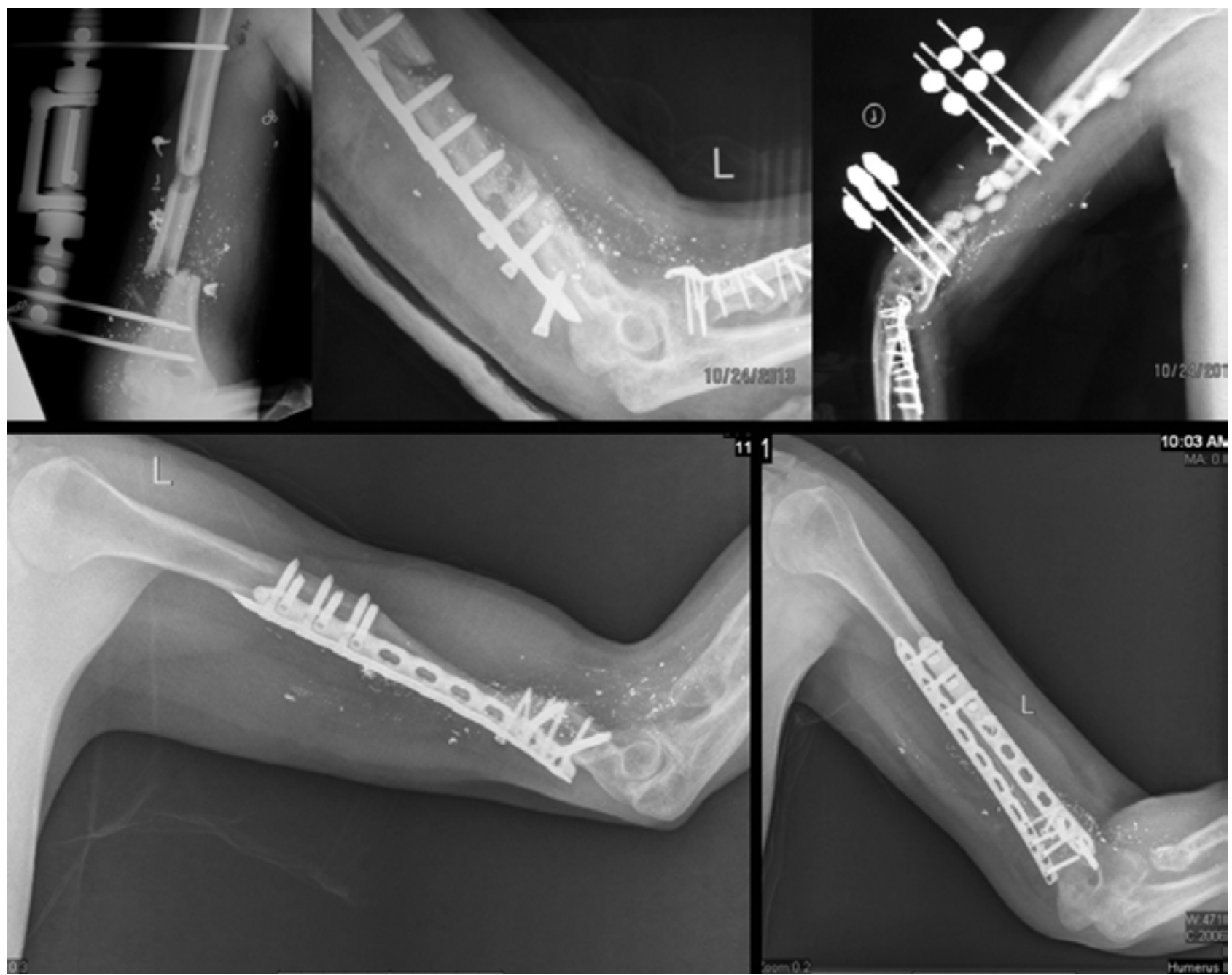

Şekil 2. Yüksek enerjili travma sonrası enfekte kaynamamaya gitmiş olan defektif humerus psödoartroz olgusunda SVFG ve çift uzun kompresyon plağı ile yapılan rekonstrüksiyon neticesinde tam kaynama izlenmektedir.

Flebin kanlanması, prosedürün başarısını belirleyen en önemli etkendir. ${ }^{[51]}$ Bunun yanı sıra, flebin canlılığını, özellikle erken dönemde, takip edebilmenin optimal bir yolu da yoktur. ${ }^{[52]}$ Cilt adası içeren kompozit fleplerde cildin kanlanması indirekt olarak klinik olarak değerlendirmeyi mümkün kılsa da, tüm flebin kanlanması hakkında yeterli bilgi sağlayamaz. Sintigrafi, lazer Doppler akım ölçer, MR anjiyografi, oksijen satürasyonu, $\mathrm{pH}$ ölçümü ve doku Isı ölçümü gibi yöntemler, hem maliyetlerinin yüksek olması hem de güvenilirliklerinin yeterli olmaması nedeniyle, flebin monitorizasyonunda sık kullanılmaz. ${ }^{[52]}$

Stres kırığı, ameliyat sonrası ilk yıl içinde \%7,7 ile $\% 22,2$ arasında değişen oranlarda bildirilmiştir. ${ }^{[53-55]}$ Tek SVFG'de stres kırığı olma ihtmali, çift namlu veya çift SVFG'ye göre daha fazladır. ${ }^{[56]}$ Stres kırı̆ı̆ın engellemek için, yeterli hipertrofi olmadan yüklenmekten kaçınmak gerekmektedir. Tedavi konservatiftir.

Non-union SVFG'nin, özellikle tibia psödoartrozlarında kullanımı sırasında, yetersiz tespit yöntemlerine bağlı olarak gelişebileceği bildirilmiştir. ${ }^{[57]}$

Alıcı sahanın yetersiz debride edildiği olgularda enfeksiyon görülebilmektedir. Tek aşamada yapılan fleplemede enfeksiyonu engellemek için, bütün devitalize ve enfekte dokuların uzaklaştırılmasını sağlayacak yeterlilikte debridmanın yapılması gereklidir. ${ }^{[58]}$

Disseksiyonda kas yastıkçığının ince alınması, donör alan hematom oranının azalmasına, pedikülün daha iyi disseksiyonuna ve dönör tarafta bacak kuvvetinin artmasına katkı sağlamaktadır. Proksimal ve 
distalde yeterli parça bırakmak kaydıyla, 25 cm'ye kadar SVFG alınabilir. Lateral malleol kısmında 10 cm'lik bir kısmın bırakılması, ayak bileği stabilitesinin bozulmaması için gereklidir. Proksimal fibulanın alınması sırasında peroneal palsi oluşabilir ama bu durum genellikle geçicidir.

\section{SONUÇ}

SVFG ile uzun kemik defektlerinin rekonstrüksiyonu, hasta için çok önemli yararlar sağlamakla beraber, cerrahın tedavi edebilmek için hazırlıklı olmasını gerektirecek ciddi potansiyel riskler de taşımaktadır. Özellikle travmatik enfekte veya non-enfekte kaynamamalara bağlı uzun kemik defektlerinin SVFG ile rekonstrüksiyonunda, sonuçların diğer etiyolojilere nazaran (tümör rezeksiyonu gibi) daha iyi olabildiği bilinmektedir. Bu gibi olgularda komplikasyonlarla mücadelenin köşe taşının, fibulanın canlılığının devamı olduğu bildirilmiştir. ${ }^{[44]}$ Serletti ve ark., cerrahi sonrası komplikasyonların gelişimi açısından buldukları tek parametrenin, uzamış cerrahi süre olduğunu bildirmişlerdir. ${ }^{[59]}$ Hasta için cerrahinin başarısızlığı, sadece rekonstrüksiyonun başarısızlığı değil, ayrıca donör sahadaki normal dokunun da feda edilmesi bağlamında bir kayıptır. ${ }^{[23]}$ Yine de, özellikle uzun kemiklerin atrofik/defektif kaynamamalarında, serbest vaskülarize fibula greftiyle uygun endikasyon ve uygun teknikle yapılacak olan bir rekonstrüktif cerrahi, sağlayacağı maksimum bölgesel kanlanma desteğiyle, yüz güldürücü iyileşme sonuçlarını da beraberinde getirir ve bu nedenle, diğer rekonstrüktif tedavi alternatiflerinin yanında efektif bir seçenek olarak yer alır.

\section{KAYNAKLAR}

1. Reed AA, Joyner CJ, Isefuku S, Brownlow HC, Simpson AH. Vacularity in a new model of atrophic nonunion. J Bone Joint Surg $\operatorname{Br} 2003 ; 85(4): 604-10$.

2. Judet R, Roy-Camille R, Guillamon JL. Treatment of pseudarthrosis of the carpal scaphoid by pediculated graft. Rev Chir Orthop Reparatrice Appar Mot 1972;58(7):699-705.

3. Ostrup LT, Fredrickson JM. Distant transfer of a free, living bone graft by microvascular anastomoses. An experimental study. Plast Reconstr Surg 1974;54(3):274-85.

4. Doi K, Tominaga S, Shibata T. Bone grafts with microvascular anastomoses of vascular pedicles: an experimental study in dogs. J Bone Joint Surg Am 1977;59(6):809-15.

5. Buncke HJ, Furnas DW, Gordon L, Achauer BM. Free osteocutaneous flap from a rib to the tibia. Plast Reconstr Surg 1977;59(6):799-804.

6. Weiland AJ, Daniel RK. Vascularised bone grafts. In: Green DP, editor. Operative Hand Surgery. New York: Churchill Livigstone; 1982. p.877.

7. Weiland AJ, Weiss AP, Moore JR, Tolo VT. Vascularized fibular grafts in the treatment of congenital pseudarthrosis of the tibia. J Bone Joint Surg Am 1990;72(5):654-62.
8. Daniel RK, Weiland AJ. Free tissue transfers for upper extremity reconstruction. J Hand Surg Am 1982;7(1):66-76.

9. GoldbergVM, ShafferJW, FieldG, DavyDT. Biology ofvascularized bone grafts. Orthop Clin North Am 1987;18(2):197-205.

10. Cutting CB, McCarthy JG. Comparison of residual osseous mass between vascularized and nonvascularized onlay bone transfers. Plast Reconstr Surg 1983;72(5):672-5.

11. Peat BG, Liggins DF. Microvascular soft tissue reconstruction for acute tibial fractures -late complications and the role of bone grafting. Ann Plast Surg 1990;24(6):517-20.

12. de Boer $\mathrm{HH}$, Wood MB. Bone changes in the vascularised fibular graft. J Bone Joint Surg Br 1989;71(3):374-8.

13. Ikeda K, Tomita K, Hashimoto F, Morikawa S. Long-term follow-up of vascularized bone grafts for the reconstruction of tibial nonunion: evaluation with computed tomographic scanning. J Trauma 1992;32(6):693-7.

14. Mizumoto S, Tamai S, Goshima J, Yajima H, Yoshii T, Fukui A, Masuhara K. Experimental study of vascularized tibiofibula graft in inbred rats: a preliminary report.J Reconstr Microsurg 1986;3(1):1-11. Crossref

15. Tu YK, Yen CY, Yeh WL, Wang IC, Wang KC, Ueng WN. Reconstruction of posttraumatic long bone defect with free vascularized bone graft: good outcome in 48 patients with 6 years' follow-up. Acta Orthop Scand 2001;72(4):359-64. Crossref

16. Yazar $\mathrm{S}$, Lin $\mathrm{CH}$, Wei FC. One-stage reconstruction of composite bone and soft-tissue defects in traumatic lower extremities. Plast Reconstr Surg 2004;114(6):1457-66.

17. Bieber EJ, Wood MB. Bone reconstruction. Clin Plast Surg 1986;13(4):645-55.

18. Jobe MT. Microsurgery. In: Canale ST, Beaty JH, editors. Campbell's Operative Orthopaedics 11 th ed. Philadelphia: Mosby Elsevier; 2008. pp.3759.

19. Jia WT, Zhang CQ, Sheng JG, Jin DX, Cheng XG, Chen SB, Zeng BF. Free vascularized fibular grafting in combination with a locking plate for the reconstruction of a large tibial defect secondary to osteomyelitis in a child: a case report and literature review. J Pediatr Orthop B 2010;19(1):66-70. Crossref

20. Blick SS, Brumback RJ, Lakatos R, Poka A, Burgess AR. Early prophylactic bone grafting of high-energy tibial fractures. Clin Orthop Relat Res 1989;(240):21-41.

21. Atkins RM, Madhavan P, Sudhakar J, Whitwell D. Ipsilateral vascularised fibular transport for massive defects of the tibia. J Bone Joint Surg Br 1999;81(6):1035-40.

22. Malizos KN, Nunley JA, Goldner RD, Urbaniak JR, Harrelson JM. Free vascularized fibula in traumatic long bone defects and in limb salvaging following tumor resection: comparative study. Microsurgery 1993;14(6):368-74.

23. Arai K, Toh S, Tsubo K, Nishikawa S, Narita S, Miura H. Complications of vascularized fibula graft for reconstruction of long bones. Plast Reconstr Surg 2002;109(7):2301-6.

24. Hou SM, Liu TK. Reconstruction of skeletal defects in the femur with 'two-strut' free vascularized fibular grafts. J Trauma 1992;33(6):840-5.

25. Taylor GI. The current status of free vascularized bone grafts. Clin Plast Surg 1983;10(1):185-209.

26. SchuSlerman MA, Reeee GP, Miller MJ, Harris S. The osteocutaneous free fibula flap. Is the skin paddle reliable? Plast Reconstr Surg 1992;90(5):787-93.

27. Kıral A, Arapcıoğlu MÖ, Sarığlu A, Kuşkucu M, Rodop O, Kaplan $\mathrm{H}$. Treatment of large segmental bone defects with free, vascularized fibular grafts. Acta Orthop Traumatol Turc 1997;31(3):216-24. 
28. Makley JT. The use of allografts to reconstruct intercalary defects of long bones. Clin Orthop Relat Res 1985;(197):58-75.

29. Pederson WC, Person DW. Long bone reconstruction with vascularized bone grafts. Orthop Clin North Am 2007;38(1):23-35. Crossref

30. Yokoyama K, Itoman M, Nakamura K, Tsukamoto T, Saita Y, Aoki S. Free vascularized fibular graft vs. Ilizarov method for post-traumatic tibial bone defect. J Reconstr Microsurg 2001;17(1):17-25.

31. Jones NF, Swartz WM, Mears DC, Jupiter JB, Grossman A. The "double barrel" free vascularized fibular bone graft. Plast Reconstr Surg 1988;81(3):378-85.

32. Capanna R, Bufalini C, Campanacci M. A new technique for reconstruction of large metadiaphyseal bone defect. Orthop Travmatol 1993;2(3):159-77. Crossref

33. Ghert M, Colterjohn N, Manfrini M. The use offree vascularized fibular grafts in skeletal reconstruction for bone tumors in children. J Am Acad Orthop Surg 2007;15(10):577-87.

34. Innocenti M, Delcroix L, Manfrini M, Ceruso M, Capanna R. Vascularized proximal fibular epiphyseal transfer for distal radial reconstruction. J Bone Joint Surg Am 2004;86-A(7):1504-11.

35. Innocenti $M$, Ceruso M, Manfrini M, Angeloni $R$, Lauri G, Capanna R, Bufalini C. Free vascularized growth-plate transfer after bone tumor resection in children. J Reconstr Microsurg 1998;14(2):137-43. Crossref

36. Manfrini $M$, Innocenti $M$, Ceruso $M$, Mercuri $M$. Original biological reconstruction of the hip in a four year old girl. Lancet 2003;361(9352):140-2. Crossref

37. Wu SP, Zhang FH, Yu FB, Zhou R. Medial malleolus and deltoid ligament reconstruction in open ankle fractures with combination of vascularized fibular head osteo-tendinous flap and free flap transfers. Microsurgery 2009;29(8):630-5. Crossref

38. Duffy GP, Wood MB, Rock MG, Sim FH. Vascularized free fibular transfer combined with autografting for the management of fracture nonunions associated with radiation therapy. J Bone Joint Surg Am 2000;82(4):544-54.

39. Jupiter JB, Bour CJ, May JW Jr. The reconstruction of defects in the femoral shaft with vascularized transfers of fibular bone. J Bone Joint Surg Am 1987;69(3):365-74.

40. Wei FC, El-Gammal TA, Lin CH, Ueng WN. Free fibula osteoseptocutaneous graft for reconstruction of segmental femoral shaft defects. J Trauma 1997;43(5):784-92.

41. Yajima $\mathrm{H}$, Tamai S. Twin-barrelled vascularized fibular grafting to the pelvis and lower extremity. Clin Orthop Relat Res 1994;(303):178-84

42. Tomita Y, Murota K, Takahashi F, Moriyama M, Beppu M. Postoperative results of vascularized double fibula grafts for femoral pseudoarthrosis with large bony defect. Microsurgery 1994;15(5):316-21.

43. Moran SL, Shin AY, Bishop AT. The use of massive bone allograft with intramedullary free fibular flap for limb salvage in a pediatric and adolescent population. Plast Reconstr Surg 2006;118(2):413-9. Crossref

44. Innocenti M, Abed YY, Beltrami G, Delcroix L, Manfrini M, Capanna R. Biological reconstruction after resection of bone tumors of the proximal tibia using allograft shell and intramedullary free vascularized fibular graft: long-term results. Microsurgery 2009;29(5):361-72. Crossref
45. Zaretski A, Amir A, Meller I, Leshem D, Kollender Y, Barnea Y, Bickels J, Shpitzer T, Ad-El D, Gur E. Free fibula long bone reconstruction in orthopedic oncology: a surgical algorithm for reconstructive options. Plast Reconstr Surg 2004;113(7):1989-2000.

46. Esser RD. Treatment of a bone defect of the forearm by bone transport: a case report. Clin Orthop Relat Res 1996;(326):221-4.

47. Villa A, Paley D, Catagni MA, Bell D, Cattaneo R. Lengthening of the forearm by the llizarov tecnique. Clin Orthop Relat Res 1990;(250):125-37.

48. Davey PA, Simonis RB. Modification of the Nicoll bonegrafting technique for nonunion of the radius and/or ulna. J Bone Joint Surg Br 2002;84(1):30-3.

49. Jupiter JB, Gerhard HJ, Guerrero J, Nunley JA, Levin LS. Treatment of segmental defects of the radius with use of the vascularized osteoseptocutaneous fibular autogenous graft. J Bone Joint Surg Am 1997;79(4):542-50.

50. Mattar R, Azze RJ, Castro Ferreira M, Starck R, Canedo AC. Vascularized fibular graft for management of severe osteomyelitis of the upper extremity. Microsurgery 1994;15(1):22-7.

51. Sakamoto A, Yoshida T, Uchida $Y$, Kojima T, Kubota $H$, Iwamoto Y. Long-term follow-up on the use of vascularized fibular graft for the treatment of congenital pseudarthrosis of the tibia. J Orthop Surg Res 2008;3:13. Crossref

52. Pliefke J, Rademacher G, Zach A, Bauwens K, Ekkernkamp A, Eisenschenk A. Postoperative monitoring of free vascularized bone grafts in reconstruction of bone defects. Microsurgery 2009;29(5):401-7. Crossref

53. Ihara K, Doi K, Yamamoto M, Kawai S. Free vascularized fibular grafts for large bone defects in the extremities after tumour excision. J Reconstr Microsurg 1998;14(6):371-6. Crossref

54. Amr SN, El-Mofty AO, Amin SN, Morsy AM, El-Malt OM, Abdel-Aal HA. Reconstruction after resection of tumours around the knee: role of the free vascularized fibular graft. Microsurgery 2000;20(5):233-51.

55. de Boer $\mathrm{HH}$, Wood MB, Hermans J. Reconstruction of large skeletal defects by vascularized fibula transfer: Factors that influenced the outcome of union in 62 cases. Int Orthop 1990;14(2):121-8.

56. Doi K, Kawakami F, Hiura Y, Oda T, Sakai K, Kawai S. Onestage treatment of infected bone defects of the tibia with skin loss by free vascularized osteocutaneous grafts. Microsurgery 1995;16(10):704-12.

57. Cavadas PC, Landín L, Ibáñez J, Nthumba P. Reconstruction of major traumatic segmental bone defects of the tibia with vascularized bone transfers. Plast Reconstr Surg 2010;125(1):215-23. Crossref

58. Song HR, Kale A, Park HB, Koo KH, Chae DJ, Oh CW, Chung DW. Comparison of internal bone transport and vascularized fibular grafting for femoral bone defects. J Orthop Trauma 2003;17(3):203-11.

59. Serletti JM, Higgins JP, Moran S, Orlando GS. Factors affecting outcome in free-tissue transfer in the elderly. Plast Reconstr Surg 2000;106(1):66-70. 